DOI: https://doi.org/10.24144/2409-6857.2020.2(56).52-61

УДК 339.137:005.332

Уманців Ю.М., Золіна Д.О.

\title{
КОНКУРЕНТНА ПОЛІТИКА ДЕРЖАВИ ЗА УМОВ ГЛОБАЛЬНИХ ТРАНСФОРМАЦІЙ
}

У статті здійснено аналіз проблем конкурентної політики в умовах новітніх глобальних викликів. Визначено, що складність процесу розвитку конкуренції обумовлює необхідність формування конкурентної політики держави. Конкурентна політика є одним із найскладніших видів економічної політики. Встановлено, що конкурентна політика держави сприяє економічній конкуренції, стимулюючи незалежних економічних суб'єктів вступати у конкурентні відносини. Визначено, що важливе значення має конкурентне регулювання, спрямоване на формування ефективної конкурентної поведінки учасників ринкового процесу в Україні.

Зроблено висновки про те, щңо реалізація дієвої конкурентної політики держави дає змогу сприяти збалансованому функиіонуванню товарних ринків, підтримувати позитивні тенденції зміни кон'юнктури та масштабів ділової активності.

Ключові слова: конкурентна політика, конкуренція, конкурентоспроможність, порушення конкурентного законодавства, захист економічної конкуренції.

Постановка проблеми. Загострення викликів, спричинених глобалізацією, зростання ризиків у всіх сферах економічного життя значної актуальності набувають проблеми при реалізації конкурентної політики, вдосконалення механізму моніторингу функціонування конкурентного середовища, захисту конкуренції та підвищення конкурентоспроможності національної економіки. Важливим науковим завданням $\epsilon$ аналіз практики реалізації конкурентної політики національними органами 3 питань конкуренції 3 метою підвищення дієвості їхньої діяльності. У цьому контексті розкриття особливостей реалізації конкурентної політики держави потребує грунтовного наукового пошуку. Дослідження складових формування ефективної та дієвої конкурентної політики дасть змогу визначити перспективні напрями імплементації найкращих світових практик в інституційне середовище України.

Аналіз останніх досліджень i публікацій. Проблеми аналізу формування та реалізації дієвої конкурентної політики за умов глобальних

(УУманців Ю.М., д.е.н., професор кафедри економічної теорії та конкурентної політики, Київський національний торговельноекономічний університет, м. Київ, Україна, E-mail: y.umantsiv@knute.edu.ua

Золіна Д.О., здобувачка освітнього ступеня «бакалавр» за спеціальністю «Управління в сфері економічної конкуренції», Київський національний торговельно-економічний університет, м. Київ, Україна, E-mail: d_zolina_femp_17_10_b_d@ @nute.edu.ua трансформацій $\epsilon$ об'єктом наукового аналізу багатьох вчених. Український науковець В. Лагутін звертає увагу на те, що «умови соціальноекономічної кризи в Україні загострили проблему конкуренції й конкурентного середовища внутрішнього ринку. Вирішення цієї проблеми в сучасних умовах пов'язано із відновленням економічного зростання, реальним переходом до інноваційно-інвестиційного типу розвитку, забезпеченням стимулюючого впливу конкуренції на вітчизняне виробництво» [1, с. 23].

Обгрунтовує позицію про те, що проблеми конкуренції $є$ важливими для держави за сучасних умов у зв'язку з ускладненням економічних умов, трансформацією конкурентного процесу, нестійкими реаліями розвитку, глобальними викликами та змінами засад державного регулювання, Л. Куліш.При цьому дослідниця цілком виважено стверджує, що важливою метою конкурентної політики є створення передумов для ефективної конкуренції, яка покликана оптимально розподіляти ресурси в економіці [2]. На думку Е. Шелудько, ключовим фактором підвищення конкурентоспроможності України має стати якраз ефективна конкурентна політика, спрямована на реструктуризацію економіки та створення законодавчої бази, що підвищує конкурентоспроможність національної продукції на внутрішньому та зовнішньому ринках [3].

В. Романенко глибоко аналізує проблеми взаємозв'язку між конкурентною політикою та конкурентоспроможністю національної економіки. При цьому автор наголошує, що «соціально-політичні та економічні виклики, які сьогодні стоять перед Україною, вимагають 
заміни акцентів в економічній політиці держави, вагомою складовою якої є конкурентна політика» $[4$, c. 5]. Т. Щербакова цілком слушно привертає увагу до необхідності здійснення адвокатування конкуренції, що є багатоаспектним комплексом заходів конкурентних органів держави, спрямованих на підтримання, розвиток і захист сумлінної конкуренції, формування конкурентної культури, підтримання принципів чесного конкурентного протистояння, забезпечення балансу різноманітних інтересів в економіці $[5, \mathrm{c}$. 48-51].

Украй актуальну проблему державного контролю за монопольним ціноутворенням аналізує у своїх працях О. Вертелєва. Дослідниця наголошує на тому, що 3 метою недопущення потенційних негативних наслідків державного втручання в цінову політику компаній слід виокремити перелік випадків, за яких доцільним буде застосування норм про монопольно високу ціну [6].

Розкриваючи проблему інформаційної асиметрії в економіці, українські дослідниці А. Герасименко та А. Нестерець дійшли висновку про здебільшого «антиконкурентний вплив інформаційної асиметрії на конкуренцію», що призводить до того, що сумлінні суб'єкти господарювання потрапляють у гірші умови конкурентного протистояння, й вимушені при цьому або залишати ринок, або застосовувати нечесні способи конкуренції для зниження впливу інформаційної асиметрії [7]. Г. Филюк вказує на те, що монополізація української економіки негативним чином впливає на економічний розвиток країни та обумовлює бар'єри для підвищення іiі конкурентоспроможності [9]. А. Щербак аргументовано доводить, що стимулювання розвитку конкуренції $\epsilon$ важливим чинником економічного зростання. Дослідник показує зв'язок між інтенсивністю внутрішньої конкуренції та динамікою ВВП України [10]. Українські вчені I. Черленяк та О. Курей аналізують вплив пандемії коронавірусу на розвиток національної економіки, а також розглядають деформації конкурентного середовища внаслідок таких викликів [11]. У наших попередніх дослідженнях розкрито проблеми розвитку економічної конкуренції за умов посилення глобалізаційних процесів та визначено напрями реалізації конкурентної політики у системі чинників активізації економічного розвитку [12; $13 ; 14]$.

Дж. Норман та Л. Пепалл здійснили глибокий аналіз процесів злиття у контексті моделі просторової конкуренції Курно. Автори досліджують економічну ефективність та наслідки злиття, коли фірми конкурують на диференційованих ринках. При цьому дослідники зазначають, що злиття двох фірм зменшує конкурентний тиск, що призводить до підвищення цін та зменшення надлишку споживачів. Крім того, злиття збільшує загальний надлишок завдяки підвищенню ефективності розміщення та зростанню прибутку фірм, що об’єднуються [15].

Індійські вчені Р. Басант та П. Мішра досліджують проблематику впливу вертикальної інтеграції на ринкову владу в індійському промисловому секторі. Використовуючи статистичні дані 3 майже п'ятдесяти провідних галузей індійської економіки протягом 2003-2004 та 2010-2011 pp. та застосовуючи системний метод для оцінки динамічних моделей панельних даних, автори виявляють, що вертикальна інтеграція не спричиняє значного впливу на середню ринкову силу фірм у галузі. Натомість на це впливає розмір ринку, а також зусилля, пов'язані 3 продажами та технологіями. Загалом наслідки впливу розміру ринку та інтенсивності технологій виявляються негативними. При цьому йдеться про те, що подібно до вертикальної інтеграції, концентрація ринку, коефіціснти імпорту та експорту, а також капіталомісткість не мають значного впливу на ринкову владу. Таким чином, дослідники доходять висновку про те, що результати їхнього дослідження мають важливе значення для та конкурентної політики [16]. Професор конкурентної політики та права Університетського коледжу Лондона Д. Манцарі відстоює думку про те, що $y$ найближчі роки однією 3 найбільших проблем, 3 якою стикатимуться учасники конкурентного процесу, стане зупинка великих технологічних компаній, які не витримають конкуренції [17]. Водночас потребують подальшого аналізу проблеми реалізації дієвої конкурентної політики за умов глобальних трансформацій.

Формування цілей статті. Метою статті $\epsilon$ розкриття теоретичних засад та узагальнення практичних аспектів формування та особливостей реалізації конкурентної політики держави за сучасних умов.

Матеріали та методи. У процесі дослідження використано такі загальнонаукові та спеціальні методи, як історико-логічний - для розгляду еволюції конкурентної політики держави; системний підхід - при дослідженні теоретичних аспектів інституційної спроможності конкурентного органу; ретроспективного та порівняльного аналізу - для виявлення впливу 
конкурентної політики на розвиток конкурентного середовища в економіці України.

Опис основного матеріалу дослідження. Конкурентна політика $є$ діяльністю держави, спрямованою на створення конкурентного середовища для компаній на ринках, а також забезпечення їх взаємодії для того, щоб уникнути дискримінації передусім у сфері монопольного ціноутворення та через зниження якості продукції [18]. 3 метою розкриття особливостей прояву конкурентної політики необхідно проаналізувати пріоритетні напрями iіi реалізації. Ефективна реалізація конкурентної політики обумовлюється цілою низкою детермінантів, які визнають роль і значення державної конкурентної політики. Йдеться про об'єктивне існування ринків 3 низькою інтенсивністю конкуренції, існування ринкової влади продавців ресурсів та виробників, диспропорції ринкової інформації (рис. 1).

Антимонопольний комітет України (АМКУ) $\epsilon$ державним органом зі спеціальним статусом, діяльність якого спрямована на забезпечення державного захисту конкуренції у підприємницькій діяльності та у публічних закупівлях. Змістовна характеристика особливого статусу Антимонопольного комітету України визначається його завданнями та повноваженнями, включаючи його роль у розробці конкурентної політики, та визначається законами, іншими нормативно-правовими актами та, зокрема, й спеціальною процедурою призначення та звільнення голови, заступників та державних уповноважених, голів територіальних відділень, наданні захисту майнових прав працівників в умовах оплати праці [19].

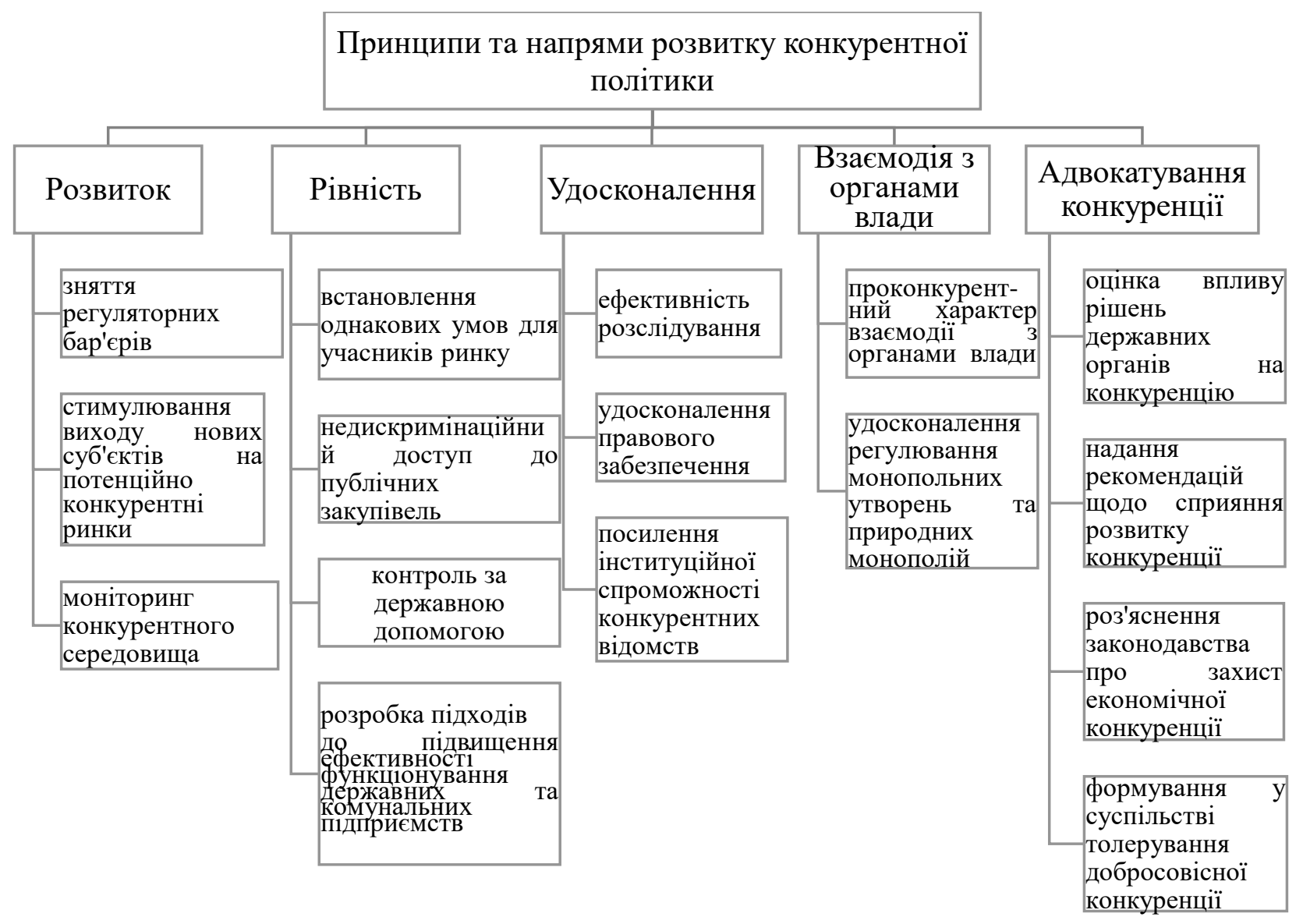

Рис. 1. Принципи та напрями розвитку конкурентної політики*

*Джерело: побудовано авторами

У процесі формування конкурентної політики слід забезпечити виважене співвідношення між діями, спрямованими на захист конкуренції, i заходами, які стимулюють розвиток конкуренції. Вагомими у цьому зв'язку $є$ два виміри конкурентної політики, а саме: діяльність конкурентних органів держави, що втілюється у певних приписах, спрямованих на усунення заборонених дій, та заходи, які забезпечують дотримання визначених правил. Політика захисту конкуренції грунтується на ідеях найменших втрат ефективності, викликаних відновленням економічних процесів унаслідок припинення антиконкурентних дій [1]. Розвиток системи інституційного забезпечення конкурентної політики в Україні наведено у таблиці 1. 
Таблиця 1

Розвиток системи інституційного забезпечення конкурентної політики в Україні*

\begin{tabular}{|c|c|c|c|}
\hline Етап & Період & Основний зміст етапу & Основне нормативно-правове забезпечення \\
\hline 1 & $\begin{array}{l}1991-1995 \\
\text { pp. }\end{array}$ & $\begin{array}{l}\text { Започаткування антимонопольного } \\
\text { законодавства в Україні, розробка } \\
\text { перших основних законів для } \\
\text { здійснення } \\
\text { економіки }\end{array}$ & $\begin{array}{l}\text { Закон України «Про обмеження монополізму } \\
\text { та недопущення недобросовісної конкуренції»; } \\
\text { Закон України Про Антимонопольний комітет } \\
\text { України»; Державна програма демоно- } \\
\text { полізації економіки і розвитку конкуренції }\end{array}$ \\
\hline 2 & $\begin{array}{l}1996-2000 \\
\text { pp. }\end{array}$ & $\begin{array}{lr}\text { Ухвалення засадничих } & \text { законів, } \\
\text { продовження } & \text { демонополізації, } \\
\text { реструктуризація } & \text { монопольних } \\
\text { ринків, поява } & \text { постійного } \\
\text { антимонопольного моніторингу }\end{array}$ & $\begin{array}{l}\text { Закон України «Про захист від недобросовісної } \\
\text { конкуренції»; Указ Президента України «Про } \\
\text { основні напрями конкурентної політики на } \\
\text { 1999-2000 роки та заходи щодо їх реалізації»; } \\
\text { Закон України «Про природні монополії» }\end{array}$ \\
\hline 3 & $\begin{array}{l}2001-2013 \\
\text { pp. }\end{array}$ & $\begin{array}{l}\text { Створення законодавчого забез- } \\
\text { печення державного регулюва-ння } \\
\text { природних монополій, ста- } \\
\text { новлення механізмів саморегу- } \\
\text { лювання ринку, створення ефек- } \\
\text { тивного механізму для подо-лання } \\
\text { інституційних монополій }\end{array}$ & $\begin{array}{l}\text { Закон України «Про захист економічної } \\
\text { конкуренції»; Указ Президента України «Про } \\
\text { основні напрями конкурентної політики на } \\
\text { 2002-2004 роки» }\end{array}$ \\
\hline 4 & $\begin{array}{l}32014 \text { p. і по } \\
\text { теперішній } \\
\text { час }\end{array}$ & 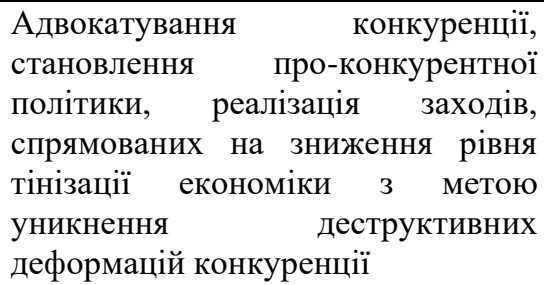 & $\begin{array}{l}\text { Концепція Загальнодержавної п програми } \\
\text { розвитку конкуренції на 2014-2024 роки }\end{array}$ \\
\hline
\end{tabular}

*Джерело: систематизовано авторами за даними: [1; 8; 13]

Проведений аналіз дає змогу дійти висновку про те, АМКУ пройшов шлях формування та розвитку, який умовно можна поділити на чотири етапи. Перший етап демонструє формування конкурентної політики, другий етап демонополізацію економіки, третій - захист вже існуючої конкуренції, а четвертий етап відображає активний захист та популяризацію активної про-конкурентної політики [8].
Уже зазначалося, що основною метою Антимонопольного комітету України є державний захист конкуренції у підприємницькій діяльності. АМКУ наділено повноваженнями щодо припинення дій, які суперечать законодавству щодо захисту економічної конкуренції. У таблиці 2 наведено найпоширеніші порушення законодавства про захист економічної конкуренції, припинені Антимонопольним комітетом протягом 2014-2019 pp.

Таблиця 2

Динаміка порушень законодавства про захист економічної конкуренції, припинених АМКУ протягом 2014-2019 рр.*

\begin{tabular}{|c|c|c|c|c|c|c|}
\hline Роки & $\begin{array}{c}\text { Всього } \\
\text { скоєно } \\
\text { порушень }\end{array}$ & $\begin{array}{c}\text { Зловживання } \\
\text { монопольним } \\
\text { становищем }\end{array}$ & $\begin{array}{c}\text { Недобросо- } \\
\text { вісна } \\
\text { конкуренція }\end{array}$ & $\begin{array}{c}\text { Антиконкурентні } \\
\text { узгджені дії суб'єк- } \\
\text { тів господарювання }\end{array}$ & $\begin{array}{c}\text { Антиконку- } \\
\text { рентні дії } \\
\text { органів влади }\end{array}$ & $\begin{array}{c}\text { Iнші } \\
\text { пору- } \\
\text { шення }\end{array}$ \\
\hline 2014 & 5341 & 2221 & 650 & 445 & 1628 & 397 \\
\hline 2015 & 4523 & 2169 & 432 & 524 & 917 & 481 \\
\hline 2016 & 3072 & 1322 & 276 & 283 & 782 & 409 \\
\hline 2017 & 2435 & 795 & 256 & 317 & 610 & 457 \\
\hline 2018 & 1344 & 216 & 168 & 263 & 454 & 243 \\
\hline 2019 & 2071 & 268 & 168 & 799 & 457 & 379 \\
\hline
\end{tabular}

*Джерело: побудовано авторами за даними: [28-33] 
Проаналізувавши звіти АМКУ за 2014-2019 pp. можна зробити висновок, що протягом останніх років сформувалася тенденція до зниження загального числа порушень законодавства про захист економічної конкуренції. Серед найбільш поширених порушень протягом останніх років можна виділити антиконкурентні узгоджені дії суб'єктів господарювання, антиконкурентні дії органів влади та зловживання монопольним становищем. Динаміка наведених вище порушень $\epsilon$ нестабільною, однак їхнє значення залишається доволі високим, що потребує вдосконалення конкурентного законодавства та посилення державного контролю за вказаними видами порушень. У цьому зв'язку необхідно також звернути увагу й на динаміку накладених штрафів Антимонопольним комітетом України у 20142019 pp., що наведена на рис. 2 (за винятком 85965,9 млн. грн. - накладеного штрафу за зловживання монопольним становищем ПАТ «Газпром» у 2016 р., 1371,3 млн. грн. антиконкурентні узгоджені дії зі спотворення аукціонів 3 продажу сирої нафти та газового конденсату у 2017 р., а також п'яти найбільших справ обсягом 8039,5 млн. грн. у 2019 р.).

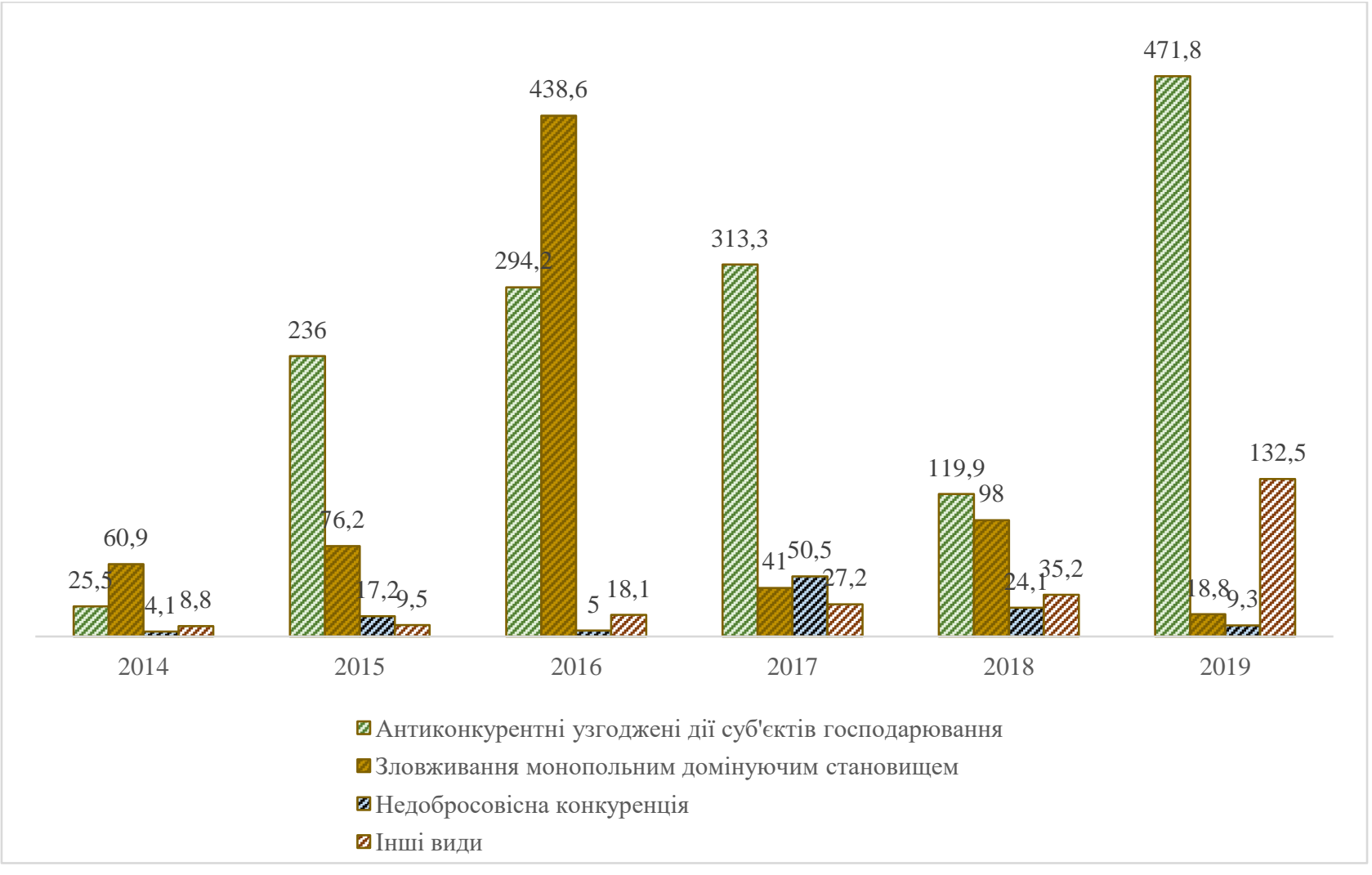

Рис. 2. Динаміка накладених штрафів Антимонопольним комітетом України у 2014-2019 pp. за видами порушень, млн. грн.*

Джерело: побудовано авторами за даними:[28-33]

*за винятком 85965,9 млн. грн. - накладеного штрафу за зловживання монопольним становищем ПАТ «Газпром» у 2016 р., 1371,3 млн. грн. - антиконкурентні узгоджені дії зі спотворення аукиіонів з продажу сирої нафти та газового конденсату у 2017 р., а також п'яти найбільших справ обсягом 8039,5 млн. грн. у 2019 р.

Аналіз наведених на рис. 2 даних ілюструє динаміку накладання штрафів Антимонопольним комітетом України протягом 2014-2019 pр. Динаміка вказує на те, що найбільшу суму штрафів було накладено у 2016 та 2019 рр. Протягом 2014 р. найбільшу суму штрафів нараховано за зловживання монопольним становищем, так само як і в 2016 та 2019 рр.
Натомість у 2015 р., а також у 2017-2018 рр. найбільшу суму штрафів було накладено за антиконкурентні узгоджені дії суб'єктів господарювання. Слід також звернути увагу на співвідношення накладених АМКУ штрафів та сплачених штрафів за порушення законодавства про захист економічної конкуренції за 2014-2019 pp., що наведено на рис. 3. 


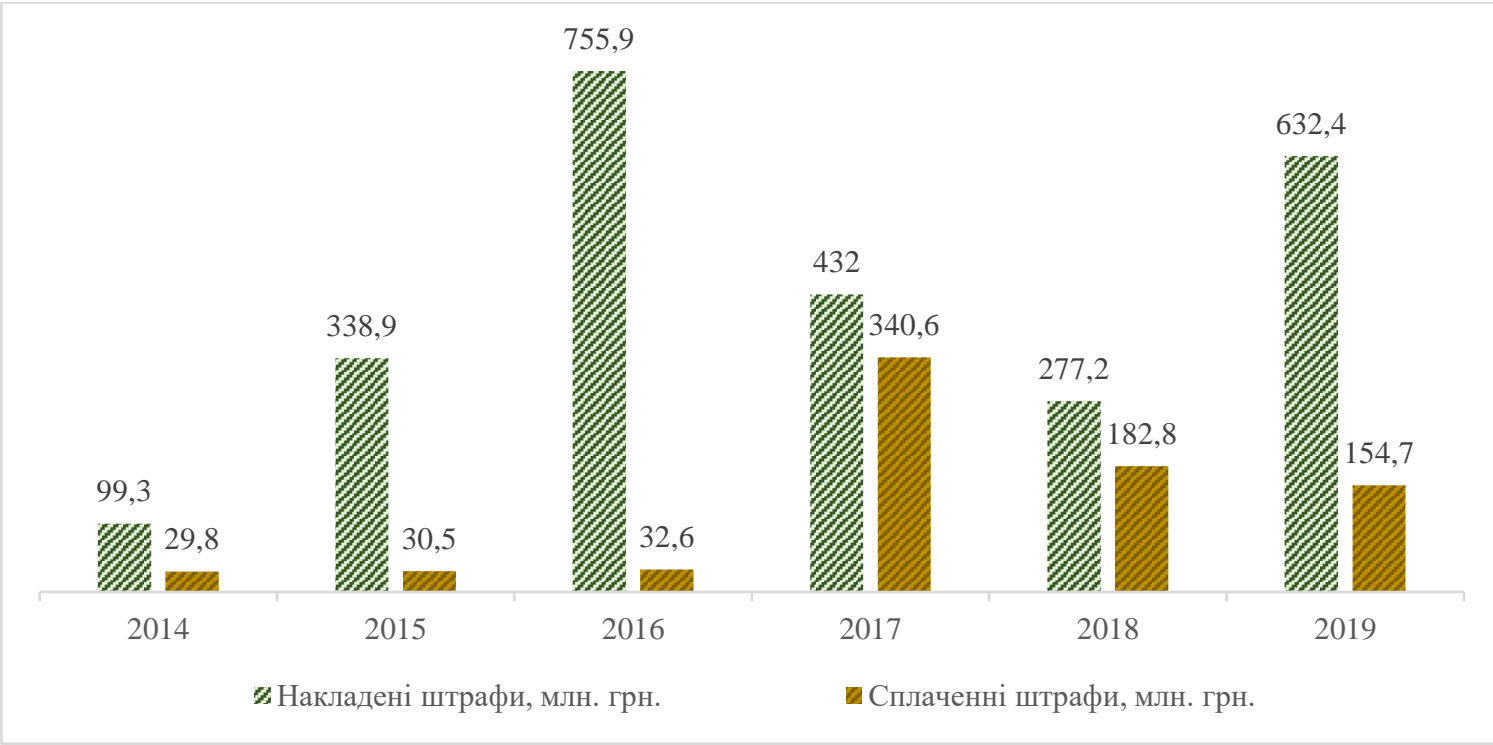

Рис. 3. Співвідношення накладених Антимонопольним комітетом штрафів та сплачених штрафів за порушення законодавства про захист економічної конкуренції у 2014-2019 рр., млн. грн.*

*Джерело: побудовано авторами за даними:[28-33]

*за винятком 85965,9 млн. грн. - накладеного штрафу за зловживання монопольним становищем ПАТ «Газпром» у 2016 р., 1371,3 млн. грн. - антиконкурентні узгоджені дії зі спотворення аукиіонів з продажу сирої нафти та газового конденсату у 2017 р., а також п'яти найбільших справ обсягом 8039,5 млн. грн. у 2019 р.

Необхідно звернути на значну різницю між сумами накладених штрафів та штрафами, сплаченими за порушення. Так, зокрема, у 2017 та 2018 рр. було зафіксовано суттєве зростання співвідношення накладених та сплачених штрафів. Антимонопольний комітет аргументує це тими обставинами, що впливають на результативність сплати штрафів. Йдеться про те, що накладення великих штрафів не приймається добровільно суб'єктами економічних відносин, а тому вони звертаються до суду. Судове провадження триває у середньому півтора року. У разі, якщо суд визнає недійсним рішення АМКУ, то конкурентний орган повинен ініціювати повторне розслідування, що вимагає фінансових ресурсів та затягує процес виконання на 1-1,5 року. Протягом цього періоду обвинувачений суб'єкт дуже часто позбувається всіх активів, унеможливлюючи виконання рішень. За таких обставин АМКУ ініціює законодавчі зміни для підвищення ефективності стягнення штрафів [33]. Однак незаперечним $є$ той факт, що розміри накладених та сплачених штрафів суттєво відрізняються, що вказує на істотні проблеми у реалізації конкурентної політики.

3 метою підвищення дієвості та ефективності конкурентної політики Антимонопольний комітет України у 2019 р. розпочав реформування територіальних відділень 3 метою наближення регіональних органів до проблем місцевого підприємництва та зменшення залежності від місцевої влади та бізнес-структур з одночасним посиленням роботи зі встановлення та припинення порушень конкурентного законодавства. При цьому очікується про-активна політика з розвитку конкуренції на місцевому рівні, базована на глибокому вивченні й розумінні локальних та регіональних трендів. У цьому зв'язку відбувається зменшення кількості територіальних відділень до шести міжрегіональних, а саме Північного, Західного, Південного, Південно-Західного, ПівденноСхідного та Східного. Нові регіональні управління АМКУ розташовані у Вінниці, Дніпрі, Києві, Львові, Одесі та Харкові. Водночас в інших обласних центрах буде організовано відокремлені відділи без статусу юридичної особи [33].

Зменшення адміністративних витрат дозволить створити гнучку та ефективну систему захисту конкуренції та запобігання порушенням, a міжрегіональні відділення отримуватимуть сучасну методологічну підтримку, а співробітники отримуватимуть кращу фінансову винагороду. Зменшення залежності від місцевої влади дасть змогу ефективніше боротися 3 антиконкурентною поведінкою цих органів влади: створенням бар'єрів для входу на ринок, дискримінаційними умовами у питаннях оренди землі, комунальної власності, доступу до ресурсів тощо. При цьому очікуваним результатом таких змін має стати й зниження потенційних ризиків корупції. Реформа територіальних відділень 
покликана створити відкрите відомство, яке систематично здійснюватиме безпосередні функції захисту конкуренції та керуватиметься інтересами держави. Необхідність реформування АМКУ закріплена у рекомендаціях ряду міжнародних організацій, зокрема, Організації економічного співробітництва та розвитку, які консультували відомство протягом останніх кількох років [33].

Водночас професор 3. Борисенко, яка тривалий час працювала на посаді першого заступника голови АМКУ, вказує на те, що без ефективної роботи обласних відділень Антимонопольний комітет не зможе охопити належним моніторингом загальнодержавні та регіональні проблеми конкуренції. Саме тому, на думку дослідниці, недоцільно ліквідовувати переважну частину територіальних відділень. Не викликає сумнівів твердження 3. Борисенко про те, що «без ефективного захисту конкуренції неможливо вивести економіку 3 кризи. Це також $\epsilon$ неодмінною умовою залучення іноземних інвестицій» [34].
Висновки i перспективи подальших досліджень. Таким чином, на основі проведеного аналізу можна дійти висновку про те, що грунтовний підхід до реалізації конкурентної політики держави базується на системних засадах. При цьому конкурентна політика спрямовується на подальше стимулювання розвитку конкурентного середовища національної економіки, захист сумлінної конкуренції, підтримання динамічного конкурентного процесу. Предметом подальших наукових досліджень мають стати підходи до обгрунтування напрямів розбудови механізму впливу конкурентної політики на розвиток економіки та підвищення іiі конкурентоспроможності за умов глобальної конкуренції. Очевидно, що недостатня дієвість конкурентної політики обумовлює втрати суспільного добробуту та зниження рівня конкурентоспроможності національних підприємств як на внутрішньому, так i на зовнішніх ринках.

\section{СПИСОК ВИКОРИСТАНИХ ДЖЕРЕЛ}

1. Лагутін В. Конкурентна політика держави: механізм реалізації. Вісник Київського національного торговельно-економічного університету. 2016. №4. С. 22-37.

2. Куліш Л. П. Конкурентна політика у системі інструментів державного регулювання економіки. Економіка і держава. 2019. №1. С. 126-131. doi. 10.32702/2306-6806.2019.1.126

3. Шелудько Е. І. Конкурентна політика як інструмент покращення функціонування ринків промислової продукції. Держава та регіони. Серія: Економіка та підприємництво. 2020. №1. С. 86-92. doi.org/10.32840/1814$1161 / 2020-1-14$

4. Романенко В. Конкурентна політика та конкурентоспроможність національної економіки. Вісник Київського національного торговельно-економічного університету. 2016. №3. С. 5-16.

5. Щербакова Т. А. Модифікація конкурентної політики за умови трансформації економічних відносин. Економіка України. 2016. №4. С. 45-56

6. Вертелєва О. В. Вектори вдосконалення державного контролю за монопольним ціноутворенням. Економічна теорія та право. 2020. №1. С. 74-97. doi: 10.31359/2411-5584-2020-40-1-74

7. Герасименко А. Г., Нестерець А. О. Вплив інформаційної асиметрії на конкуренцію. Економічний вісник. 2019. №3. C. 25-32.doi.org/10.33271/ev/67.025

8. Ясько Ю. І. Інституційне забезпечення конкурентної політики держави. Інвестиції: практика та досвід. 2020. №19. C. 74-79. doi.10.32702/2306-6814.2020.19-20.74

9. Филюк Г. М. Високий рівень монополізації української економіки - бар'єр на шляху підвищення рівня іiі конкурентоспроможності. Вісник Кам'янець-Подільського національного університету імені Івана Огієнка. Економічні науки. 2015. Вип. 10. С. 102-109.

10. Щербак А. В. Національна конкурентна політика - шлях до ефективної економіки України. Економіка і прогнозування. 2020. №1. С. 32-46. doi.org/10.15407/eip2020.01.032

11. Черленяк I. І., Курей О. А. Виклики антикризового управління економікою в умовах пандемії. Науковий вісник Ужгородського університету. Серія: Економіка. 2020. №1. С. 10-18. doi.org/10.24144/24096857.2020.1(55).10-18

12. Уманців Ю. М. Економічна конкуренція в умовах фінансової глобалізації. Фінанси України. 2009. №10. С. 95-106.

13. Уманців Ю. М., Дуцька А. С. Конкурентна політика у системі чинників активізації економічного розвитку. Вісник Кременчуцького національного університету імені Михайла Остроградського. Сер.: Економічні науки. 2014. №1. C. 29-37.

14. Уманців Ю. М., Дуцька А. С. Розвиток економічної конкуренції за умов посилення глобалізаційних процесів. Актуальні проблеми міжнародних відносин. 2014. Вип. 121. Ч. 2. С. 91-98. 
15. Norman, G., Pepall, L. (2000). Profitable Mergers in a Cournot Model of Spatial Competition. Southern Economic Journal. Vol. 66. N. 3. P. 667-681. doi:10.2307/1061431

16. Basant, R., Mishra, P. (2019). Impact of Vertical Integration on Market Power in Indian Manufacturing Sector During the Post-Reform Period. Journal of Industry, Competition and Trade. Vol. 19. P. 561581. doi.org/10.1007/s10842-019-00294-4

17. Mantzari D. (2020). Interim Measures in EU Competition Cases: Origins, Evolution, and Implications for Digital Markets. Journal of European Competition Law \& Practice. Vol. 11. Issue 9. P. 487-498. doi.org/10.1093/jeclap/lpaa045

18. Господарський кодекс України. URL: https://zakon.rada.gov.ua/laws/show/436-15\#n57

19. Про Антимонопольний комітет України: Закон України від 26.11.1993 p. № 3660-XII. URL: https://zakon.rada.gov.ua/laws/show/3659-12\#Text

20. Про обмеження монополізму та недопущення недобросовісної конкуренції у підприємницькій діяльності: Закон України від 18.02.1992 p. № 2133-XII. URL: https://zakon.rada.gov.ua/laws/show/2132-12\#Text

21. Про державну програму демонополізації економіки і розвитку конкуренції: постанова Верховної Ради України від 21.12. 1993 р. № 3757-XII. URL: https://zakon.rada.gov.ua/laws/show/3757-12\#Text

22. Про захист від недобросовісної конкуренції: Закон України від 07.06.1996 р. № 237/96-BP. URL: https://zakon.rada.gov.ua/laws/show/236/96-\%D0\%B2\%D1\%80\#Text

23. Про основні напрямки конкурентної політики на 1999-2000 роки та заходи щодо їх реалізації: указ президента України від 26.02. 1999 р. № 219/99 URL: https://zakon.rada.gov.ua/laws/show/219/99\#Text

24.Про природні монополії: Закон України від 20.04. 2000 p. №1682-III. URL: https://zakon.rada.gov.ua/laws/show/1682-14\#Text

25. Про захист економічної конкуренції: Закон України від 11.01. 2001 p. № 2210-III. URL: https://zakon.rada.gov.ua/laws/show/2210-14\#Text

26. Про основні напрями конкурентної політики на 2002-2004 роки: указ президента України від 19.11. 2001 p. №1097/2001. URL: https://zakon.rada.gov.ua/laws/show/1097/2001\#Text

27. Про схвалення Концепції Загальнодержавної програми розвитку конкуренції на 2014-2024 роки: розпорядження Кабінету Міністрів від 19.09.2012 p. № 690-p. URL: https://zakon.rada.gov.ua/laws/show/690-2012$\% \mathrm{D} 1 \% 80 \# \mathrm{Text}$

28. Звіт Антимонопольного комітету України за 2014 рік від 12.03.2015 p. URL: https://amcu.gov.ua/pronas/zvitnist/richni-zviti/zvit-2014

29. Звіт Антимонопольного комітету України за 2015 рік від 14.03.2016. URL: https://amcu.gov.ua/pronas/zvitnist/richni-zviti/zvit-2015

30. Звіт Антимонопольного комітету України за 2016 рік від 14.03.2017. URL: https://amcu.gov.ua/pronas/zvitnist/richni-zviti/zvit-2016

31. Звіт Антимонопольного комітету України за 2017 рік від 28.02.2018. URL: https://amcu.gov.ua/pronas/zvitnist/richni-zviti/zvit-2017

32. Звіт Антимонопольного комітету України за 2018 рік від 12.03.2019. URL: https://amcu.gov.ua/pronas/zvitnist/richni-zviti/zvit-2018

33. Звіт Антимонопольного комітету України за 2019 рік від 12.03.2020. URL: https://amcu.gov.ua/pronas/zvitnist/richni-zviti/zvit-2019

34. Борисенко 3. Монополія на антимонополію. URL: https://zn.ua/ukr/internal/monopoliya-na-antimonopoliyu345958_html

\section{REFERENCES}

1. Lahutin, V. (2016). Konkurentna polityka derzhavy: mekhanizm realizatsiyi [Competitive policy of the state: the mechanism of implementation]. Visnyk Kyyivs'koho natsional'noho torhovel'no-ekonomichnoho universytetu - Bulletin of Kyiv National University of Trade and Economics, 4, 22-37 [in Ukrainian].

2. Kulish, L. P. (2019). Konkurentna polityka u systemi instrumentiv derzhavnoho rehulyuvannya ekonomiky [Competition policy in the system of instruments of state regulation of the economy]. Ekonomika i derzhava - Economy and state, 1, 126-131 [in Ukrainian].

3. Shelud'ko, E. I. (2020). Konkurentna polityka yak instrument pokrashchennya funktsionuvannya rynkiv promyslovoyi produktsiyi [Competition policy as a tool to improve the functioning of industrial markets]. Derzhava ta rehiony. Seriya: Ekonomika ta pidpryyemnytstvo - State and regions. Series: Economics and Entrepreneurship, 1, 86-92 [in Ukrainian].

4. Romanenko, V. (2016). Konkurentna polityka ta konkurentospromozhnist' natsional'noyi ekonomiky [Competitive policy and competitiveness of the national economy]. Visnyk Kyyivs'koho natsional'noho torhovel'no-ekonomichnoho universytetu - Bulletin of Kyiv National University of Trade and Economics, 3, 5-16 [in Ukrainian].

5. Shcherbakova, T. A. (2016). Modyfikatsiya konkurentnoyi polityky za umovy transformatsiyi ekonomichnykh vidnosyn [Modification of competition policy under the condition of transformation of economic relations]. Ekonomika Ukrayiny - Ukraine economy, 4, 45-56 [in Ukrainian]. 
6. Vertelyeva, O. V. (2020). Vektory vdoskonalennya derzhavnoho kontrolyu za monopol'nym tsinoutvorennyam [Vectors for improving state control over monopoly pricing]. Ekonomichna teoriya ta pravo - Economic theory and law, 1, 74-97 [in Ukrainian].

7. Herasymenko, A. H., \& Nesterets', A. O. (2016). Vplyv informatsiynoyi asymetriyi na konkurentsiyu [Influence of information asymmetry on competition]. Ekonomichnyy visnyk - Economic Bulletin, 3, 25-32 [in Ukrainian].

8. Yas'ko, Yu. I. (2020). Instytutsiyne zabezpechennya konkurentnoyi polityky derzhavy [Institutional support of state competition policy]. Investytsiyi: praktyka ta dosvid - Investments: practice and experience, 19, 74-79 [in Ukrainian].

9. Fylyuk, H. M. (2015). Vysokyy riven' monopolizatsiyi ukrayins'koyi ekonomiky - baryer na shlyakhu pidvyshchennya rivnya yiyi konkurentospromozhnosti [High level of monopolization of the Ukrainian economy - a barrier to increase its level of competitiveness]. Visnyk Kamyanets'-Podil's'koho natsional'noho universytetu imeni Ivana Ohiyenka. Ekonomichni nauky - Bulletin of Kamyanets-Podilsky National University named after Ivan Ogienko. Economic sciences, 10, 102-109 [in Ukrainian].

10. Shcherbak, A. V. (2020). Natsional'na konkurentna polityka - shlyakh do efektyvnoyi ekonomiky Ukrayiny [National competition policy - the path to an efficient economy of Ukraine]. Ekonomika i prohnozuvannya - Economics and forecasting, 1, 32-46 [in Ukrainian].

11. Cherlenyak, I. I., \& Kurey, O. A. (2020). Vyklyky antykryzovoho upravlinnya ekonomikoyu v umovakh pandemiyi [Challenges of crisis management of the economy in a pandemic]. Naukovyy visnyk Uzhhorods'koho universytetu. Seriya: Ekonomika - Scientific Bulletin of Uzhhorod University. Series: Economics, 1, 10-18 [in Ukrainian].

12. Umantsiv, Yu. M. (2009). Ekonomichna konkurentsiya v umovakh finansovoyi hlobalizatsiyi [Economic competition in the context of financial globalization]. Finansy Ukrayiny - Finance of Ukraine, 10, 95 -106 [in Ukrainian].

13. Umantsiv, Yu. M., \& Duts'ka, A. S. (2014). Konkurentna polityka u systemi chynnykiv aktyvizatsiyi ekonomichnoho rozvytku [Competitive policy in the system of factors of activation of economic development]. Visnyk Kremenchuts'koho natsional'noho universytetu imeni Mykhayla Ostrohrads'koho. Ser.: Ekonomichni nauky - Bulletin of Kremenchug National University named after Mykhailo Ostrogradsky. Ser .: Economic Sciences, 1, 29-37 [in Ukrainian].

14. Umantsiv, Yu. M., \& Duts'ka, A. S. (2014). Rozvytok ekonomichnoyi konkurentsiyi za umov posylennya hlobalizatsiynykh protsesiv [Development of economic competition in the context of increasing globalization processes]. Aktual'ni problemy mizhnarodnykh vidnosyn - Current issues of international relations, 121/2, 91-98 [in Ukrainian].

15. Norman, G., \& Pepall, L. (2000). Profitable Mergers in a Cournot Model of Spatial Competition. Southern Economic Journal, 66/3, 667-681 [in English].

16. Basant, R., \& Mishra, P. (2019). Impact of Vertical Integration on Market Power in Indian Manufacturing Sector During the Post-Reform Period. Journal of Industry, Competition and Trade, 19, 561-581 [in English].

17. Mantzari, D. (2020). Interim Measures in EU Competition Cases: Origins, Evolution, and Implications for Digital Markets. Journal of European Competition Law \& Practice, 11/9, 487-498 [in English].

18. Hospodars'kyy kodeks Ukrayiny [Economic Code of Ukraine]. (n.d.). Retrieved from: https://zakon.rada.gov.ua/laws/show/436-15\#n57 [in Ukrainian].

19. Pro Antymonopol’nyy komitet Ukrayiny: Zakon Ukrayiny vid 26.11.1993 r. № 3660-XII [On the Antimonopoly Committee of Ukraine: Law of Ukraine from November 26, 1993 № 3660-XII]. (1993). Retrieved from: https://zakon.rada.gov.ua/laws/show/3659-12\#Text [in Ukrainian].

20. Pro obmezhennya monopolizmu ta nedopushchennya nedobrosovisnoyi konkurentsiyi u pidpryyemnyts'kiy diyal'nosti: Zakon Ukrayiny vid 18.02.1992 r. № 2133-XII [On the restriction of monopoly and prevention of unfair competition in business: Law of Ukraine from 18.02.1992 № 2133-XII]. (1992). Retrieved from: https://zakon.rada.gov.ua/laws/show/2132-12\#Text [in Ukrainian].

21. Pro derzhavnu prohramu demonopolizatsiyi ekonomiky i rozvytku konkurentsiyi: postanova Verkhovnoyi Rady Ukrayiny vid 21.12. 1993 r. № 3757-XII [About the state program of demonopolization of economy and development of competition: the resolution of the Verkhovna Rada of Ukraine from 21.12.1993 № 3757-XII]. (1993). Retrieved from: https://zakon.rada.gov.ua/laws/show/3757-12\#Text [in Ukrainian].

22. Pro zakhyst vid nedobrosovisnoyi konkurentsiyi: Zakon Ukrayiny vid 07.06.1996 r. № 237/96-VR. [On protection against unfair competition: Law of Ukraine from 07.06.1996 № 237/96-VR]. (1996). Retrieved from: https://zakon.rada.gov.ua/laws/show/236/96-\%D0\%B2\%D1\%80\#Text

23. Pro osnovni napryamky konkurentnoyi polityky na 1999-2000 roky ta zakhody shchodo yikh realizatsiyi: ukaz prezydenta Ukrayiny vid 26.02. 1999 r. № 219/99 [On the main directions of competition policy for 1999-2000 and measures for their implementation: Decree of the President of Ukraine from 26.02.1999 № 219/99]. (1999). Retrieved from: https://zakon.rada.gov.ua/laws/show/219/99\#Text [in Ukrainian].

24. Pro pryrodni monopoliyi: Zakon Ukrayiny vid 20.04. 2000 r. №1682-III. [On natural monopolies: Law of Ukraine from 20.04. 2000 №1682-III]. (2000). Retrieved from: https://zakon.rada.gov.ua/laws/show/1682-14\#Text [in Ukrainian].

25. Pro zakhyst ekonomichnoyi konkurentsiyi: Zakon Ukrayiny vid 11.01. 2001 r. № 2210-III [On protection of economic competition: Law of Ukraine from 11.01.2001 № 2210-III]. (2001). Retrieved from: https://zakon.rada.gov.ua/laws/show/2210-14\#Text [in Ukrainian]. 
26. Pro osnovni napryamy konkurentnoyi polityky na 2002-2004 roky: ukaz prezydenta Ukrayiny vid 19.11. 2001 r. №1097/2001. [On the main directions of competition policy for 2002-2004: the decree of the President of Ukraine from 19.11.2001 №1097 / 2001]. (2001). Retrieved from: https://zakon.rada.gov.ua/laws/show/1097/2001\#Text [in Ukrainian].

27. Pro skhvalennya Kontseptsiyi Zahal'noderzhavnoyi prohramy rozvytku konkurentsiyi na 2014-2024 roky: rozporyadzhennya Kabinetu Ministriv vid 19.09.2012. № 690-r. [n approval of the Concept of the National Competition Development Program for 2014-2024: Order of the Cabinet of Ministers from September 19, 2012 № 690-r]. (2012). Retrieved from: https://zakon.rada.gov.ua/laws/show/690-2012-\%D1\%80\#Text [in Ukrainian]

28. Zvit Antymonopol'noho komitetu Ukrayiny za 2014 rik vid 12.03.2015. [Report of the Antimonopoly Committee of Ukraine for 2014 dated March 12, 2015]. (2015). Retrieved from: https://amcu.gov.ua/pro-nas/zvitnist/richni-zviti/zvit2014 [in Ukrainian].

29. Zvit Antymonopol'noho komitetu Ukrayiny za 2015 rik vid 14.03.2016. [Report of the Antimonopoly Committee of Ukraine for 2015 dated March 14, 2016]. (2016). Retrieved from: https://amcu.gov.ua/pro-nas/zvitnist/richni-zviti/zvit2015 [in Ukrainian].

30. Zvit Antymonopol'noho komitetu Ukrayiny za 2016 rik vid 14.03.2017. [Report of the Antimonopoly Committee of Ukraine for 2016 dated March 14, 2017]. (2017). Retrieved from: https://amcu.gov.ua/pro-nas/zvitnist/richni-zviti/zvit2016 [in Ukrainian].

31. Zvit Antymonopol'noho komitetu Ukrayiny za 2017 rik vid 28.02.2018. [Report of the Antimonopoly Committee of Ukraine for 2017 dated February 28, 2018]. (2018). Retrieved from: https://amcu.gov.ua/pro-nas/zvitnist/richnizviti/zvit-2017 [in Ukrainian].

32. Zvit Antymonopol'noho komitetu Ukrayiny za 2018 rik vid 12.03.2019. [Report of the Antimonopoly Committee of Ukraine for 2018 dated March 12, 2019]. (2019). Retrieved from: https://amcu.gov.ua/pro-nas/zvitnist/richni-zviti/zvit2018 [in Ukrainian].

33. Zvit Antymonopol'noho komitetu Ukrayiny za 2019 rik vid 12.03.2020. [Report of the Antimonopoly Committee of Ukraine for 2019 dated March 12, 2020]. (2020). Retrieved from: https://amcu.gov.ua/pro-nas/zvitnist/richni-zviti/zvit2019 [in Ukrainian].

34. Borysenko, Z. Monopoliya na antymonopoliyu. [Monopoly on antitrust]. (n.d.). Retrieved from: https://zn.ua/ukr/internal/monopoliya-na-antimonopoliyu-345958_.html [in Ukrainian].

Отримано 05.12.2020 